Journal of Educational Technology

$\&$ Online Learning

Volume 5 | Issue 1 | 2022

http://dergipark.org.tr/jetol

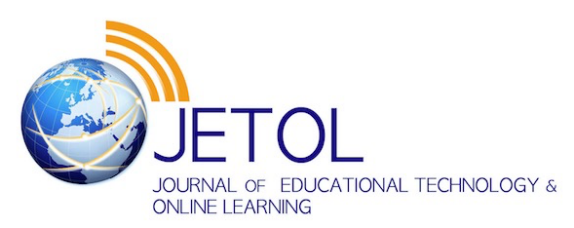

\title{
Parents' views on distance education during the Covid-19 pandemic
}

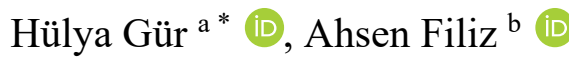 \\ a University, Necatibey Education Faculty, Turkey. \\ b Balıkesir University, Science Institue, Turkey.
}

Suggested citation: Gür, H. \& Filiz, A. (2022). Parents' views on distance education during the Covid-19 pandemic. Journal of Educational Technology \& Online Learning, 5(1), 84-104.

\begin{tabular}{ll}
\hline Article Info & $\begin{array}{l}\text { Abstract } \\
\text { Keywords: }\end{array}$ \\
$\begin{array}{l}\text { This study was conducted to reveal how parents perceive the distance education process } \\
\text { during the Covid-19 pandemic. The study group consists of } 15 \text { participants in Lüleburgaz } \\
\text { district of Kirklareli province. The case study design, one of the qualitative research } \\
\text { methods, was used in the study and data were collected online with a semi-structured } \\
\text { Parents' views }\end{array}$ & $\begin{array}{l}\text { interview form. Demographic characteristics, problems experienced by parents in } \\
\text { distance education during the Covid-19 pandemic, positive and negative experiences, } \\
\text { and opinions were interrogated via "Google Forms". The descriptive analysis and content } \\
\text { analysis methods were preferred to analyse data. The results showed that parents } \\
\text { attributed the inability to learn efficiently during the Covid-19 process to the inefficacy } \\
\text { of online education, distraction, anxiety, environment, and noise. Trainings can be given } \\
\text { to parents so that they can help their children efficiently in the distance education process. } \\
\text { It is recommended that internet infrastructure be strengthened to deal with connection } \\
\text { problems. }\end{array}$ \\
\hline
\end{tabular}

\section{Introduction}

Education is a lifelong process that includes training individuals for a specific purpose. If the planned and systematic education process is interrupted and educational activities cannot be continued, the process may be adversely affected. It is important to continue the education activities in a planned manner in cases where face-to-face education cannot be continued due to a number of reasons, such as disasters, crisis, and outbreaks. The Covid-19 pandemic, which emerged in 2019 and has been still ongoing, has negatively affected the world and become an important problem for our country. The number of Covid-19 cases, increasing rapidly worldwide, has also caused anxiety and concerns in our society. This directly affected the education and caused school closures. More than $90 \%$ of students were affected because of school closure. Since most of the states during the Covid-19 pandemic were interested in protecting their economies, they continued their education by initiating special precautionary packages. With the closure of schools, students in our country continued their education through distance education, similar to other countries.

\section{Literature}

Distance education is an interdisciplinary field that learns, teaches and removes the boundaries of learning through technology (Elçiçek, 2021). Distance education, carried out by teachers and students to

\footnotetext{
* Corresponding author. Mathematics and Science Education Department, Balikesir University, Turkey.

e-mail address: hgur@balikesir.edu.tr
} 
communicate in different places, in the same or different time periods, is provided through television and the internet in our country (Külekçi Akyavuz and Çakın, 2020).

The idea of the distance education in Turkey was first introduced at a meeting held in 1927, and was put into practice in 1950. Studies continued rapidly after 1950, and with the growing demand for a higher education, the distance education program was initiated by the Ministry of National Education under the name of teaching by letter in 1960 (Arslan and Korkmaz, 2019). With the foundation of Anadolu University Open Education Faculty in 1982, the distance education program spread (Külekçi Akyavuz and Çakın, 2020). Today, many universities such as Anadolu University, Sakarya University, Istanbul University, Marmara University, Kocaeli University and İnönü University have distance education programs in an interactive way. The Ministry of National Education has been closely following the technological advances in the world and has led to the creation of digital educational applications such as the Fatih Project, and Education Information Network (EIN) (EBA-Eğitim Bilişim Ağı) (Bayburtlu, 2020).

During the Covid-19 pandemic, different digital learning platforms have been created and typical education practices and models have been integrated. Within the scope of Education Information Network (EIN), primary school, middle school, secondary school, high school, and university level classes are broadcast in TV channels (2020). In the EIN website, students can follow lessons and benefit from various materials and videos. In addition, they can ask questions about the subjects synchronously. Teachers give homework to students through the EIN website and hence follow their progress. Due to the current pandemic, students follow their lessons via the EIN. During the Elazığ and Van earthquakes in the past, schools had to be closed, and students continued their education through the EIN system. When the studies on distance education are examined, it is seen that there is no consensus among scholars regarding the usefulness of distance education. Bayburtlu (2020) examined the views of Turkish teachers on distance education in Turkey.

The study showed that the teachers experience some connection problems in the EIN live lesson application, the students do not adequately participate in classes, the parents are indifferent to the process, and the distance education causes screen addiction among the students. Barış and Çankaya (2016) investigated the views of academic staff on distance education. They found that being independent of time and place and providing the opportunity for repetition are some key components of distance education. However, there are some disadvantages such as the low participation rate, the lack of interaction, and avoidance of taking responsibility. In another study examining the views of science teachers about distance education in the pandemic process, it was concluded that teachers experience internet connection problems during the distance education, along with the lack of communication and low student participation. Additionally, students feel themselves inadequate and anxious due to lack of knowledge (Görgülü Arı and Hayır Kanat, 2020). In their studies, Budak and Korkmaz (2020) evaluated the Covid-19 pandemic by considering the impact of the pandemic process around the world, including Turkey. The most striking finding of the study was that there is a need to re-plan our future lives to be able to deal with pandemics and to act in line with the interests of humanity, instead of individual interests, both as countries and as humanity.

In this current study, we tried to investigate the problems experienced by parents in distance education, their positive and negative experiences and their opinions during the Covid-19 pandemic process. It should be noted that most studies in the literature examined the opinions of teachers, students, academic staff and managers during the pandemic process, but there is a limited number of studies focused on parents' opinions. Thus, this study aimed to fill this gap in the literature.

For this purpose, the following questions were asked to parent through the questionnaire (Cov19MSPIF):

1. How do you evaluate the distance education carried out in the Covid-19 pandemic period? Do you think Education Information Network (EIN) is used effectively?

2. What are the problems you experience in distance education during the Covid-19 period?

3. How did the distance education process affect your children's interest in the lesson during the Covid-19 pandemic period? How can your child's interest in classes be increased? 
4. What are the positive and negative experiences you have in distance education during the Covid-19 period?

5. Do you think the distance education process during the Covid-19 pandemic is efficient for your child? Why?

6. What are the attendance levels of your children in the distance education process during the Covid-19 pandemic period?

7. What do you think about the success of your children in the distance education process during the Covid-19 pandemic?

8. As a parent, have you contributed to your child in the distance education process? How?

\subsection{The Significance of Research}

The closure of schools has helped to prevent the spread of disease in many ways. Students could not come together and were not in close contact, which minimized the risk of spreading and thus the spread of disease was slowed. However, the distance education model has revealed several shortcomings. Students have faced such a situation for the first time and followed the pandemic via social media. Accordingly, students have had different experiences of dealing with this situation. Ewing (2020) asserted that teachers' online instruction is more than merely imitating classroom instruction. On the other hand, the parental factor plays an important role in making sense of this process by children. For this reason, it is important how parents perceive this process as they are very close to students and reliable sources of information. The behaviours that parents display is important both to ensure that their children use technology efficiently and manage the process in a disciplined and trouble-free manner without restricting their children.

It should be noted that before the Covid-19 outbreak, parents had responsibilities such as supporting children, contributing to their studies, and meeting their social needs. During the pandemic, parents faced a situation that they have not experienced before. Because the pandemic has led to the social isolation of children from their friends, schools and routine life and caused stress, parents have had difficulty in balancing multiple responsibilities at the same time as caregivers and educators (Karpman, Gonzalez, \& Kenney, 2020). It is a certain fact that the Covid-19 outbreak caused parents to have difficulties in preparing and supporting their children for a different education system, and in this process, parents have had to help their children by supporting their education at home (Aslanargun, 2007, Castro, 2015, Wadley, 2020).

\section{Methodology}

This study aimed to analyse what middle school parents think about the effects of the Covid-19 pandemic on middle school education. There is some evidence that Covid-19 pandemic has advanced the use of virtual research methods. Also, the internet has become more accessible and the number of internet users has greatly increased, which has led to the rising popularity of virtual research in social sciences. The qualitative research could play a fundamental role in understanding phenomena such as Covid-19 by using virtual methods effectively. Thus, researchers need applicable technical expertise, validity and quality assurance mechanisms, and training on technology skills to practice virtual research enquiry.

\subsection{Research Model/Design}

In this current study was used case study that one of the qualitative research methods (Patton, 2002). The case study is used to define, explain and evaluate the details that form single or multiple events (Büyüköztürk at al., 2017). The objective of the study is to justify how people know and make sense of their shared experiences (Creswell, 2007; Yıldırım \& Şimşek, 2011).

\subsection{Data Collecting Tools}

In Figure 1 below, the data collection process is given. 


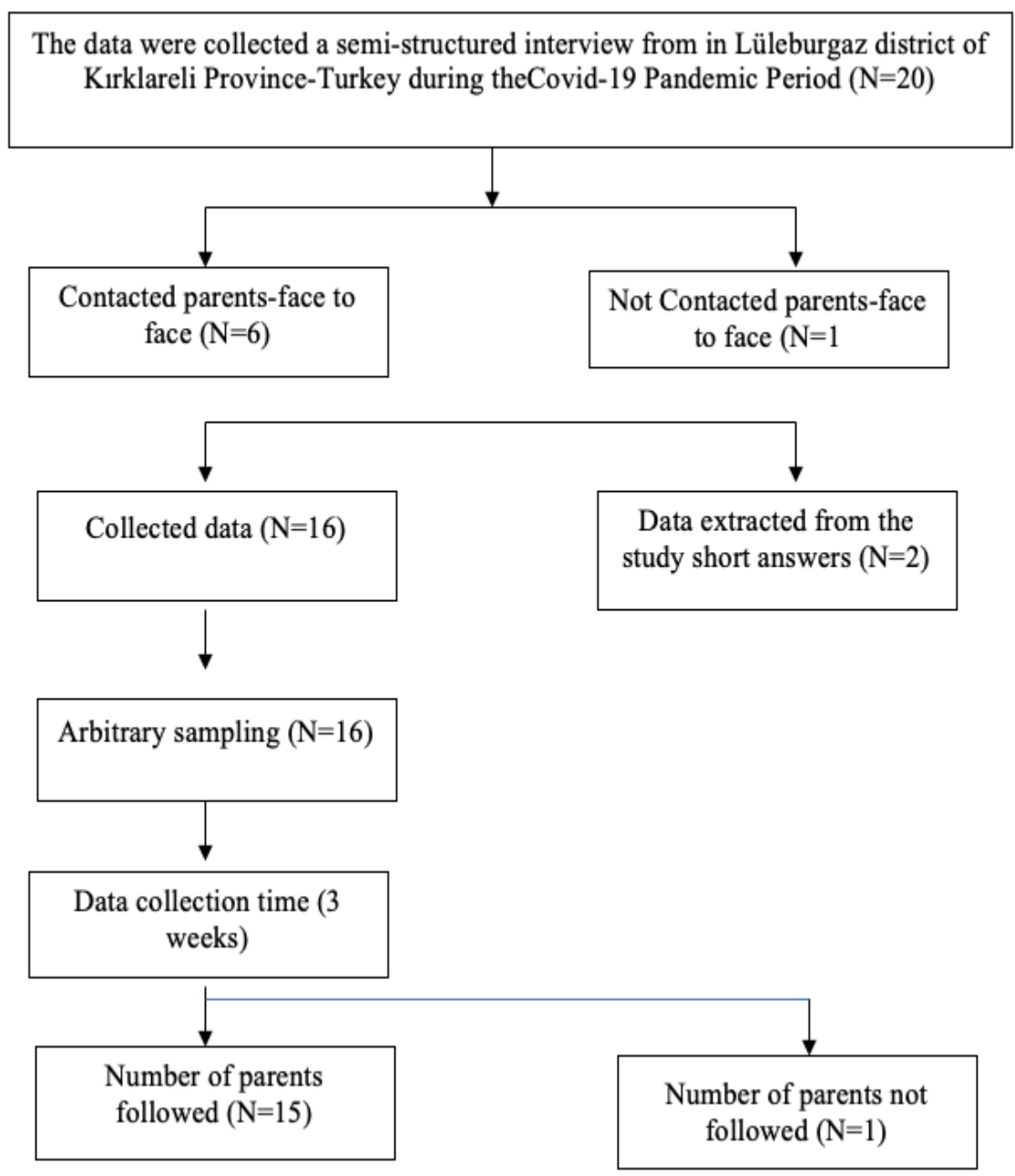

Fig. 1. Data collection process

As seen in Figure 1, due to the Covid-19 pandemic process, face-to-face interviews could not be conducted with all parents. Only 6 parents were interviewed face to face and the voice recordings were taken with their permission. Research questions of the Cov19MSPIF were sent to the participants via "Google Forms" and their answers were collected in this way.

\subsection{Study Group}

Criterion sampling, a purposive sampling method, was used to choose participants. Yıldırım \& Şimşek (2011) suggested that criterion sampling is to select a sample that satisfies a set of predetermined criteria. In other words, Patton (2002) asserted that criterion sampling is a time\&cost-efficient methods. The research was carried out in the Fall-Semester of 2020-2021 academic year, while the Covid-19 outbreak was ongoing, in district of Kirklareli Province. The study group of this research consisted of 15 parents. They were participated voluntarily.

Table 1.

Information on demographic characteristics of participants

\begin{tabular}{|c|c|c|c|}
\hline & & Frequency & Percent (\%) \\
\hline \multirow[t]{2}{*}{ Gender } & Female & 10 & 67 \\
\hline & Male & 5 & 33 \\
\hline \multirow[t]{3}{*}{ Age } & $25-35$ & 7 & 47 \\
\hline & $36-45$ & 5 & 33 \\
\hline & $46-55$ & 3 & 20 \\
\hline
\end{tabular}




$\begin{array}{lllr}\text { Education Status } & \text { Primary School Graduate } & 1 & 7 \\ & \text { Secondary School Graduate } & 2 & 13 \\ & \text { High School Graduate } & 4 & 26 \\ & \text { University Graduate } & 7 & 47 \\ & \text { Master-Doctorate Graduate } & 1 & 7 \\ \text { Number of Siblings } & \text { One } & 5 & 33 \\ & \text { Two } & 8 & 54 \\ & \text { Three and above } & 2 & 13\end{array}$

As seen in Table 1, of the parents, one had a primary school degree, two had a secondary school degree, four had a high school degree, seven had a bachelor's degree, and one had a master's degree. Also, five had one child, eight had two children and two had three or more children. The study was conducted by selecting an easily accessible case sampling. Information on the demographic characteristics of the participants forming the study group is given in Table 1. The selection criteria for parents were: (1) having a child who is a middle school student, (2) being in contact with middle school teachers and providing education to their children, and (3) being voluntary to participate in the study. The sample consisted of 15 middle school parents (10 female, 5 male). In the present study, data were collected by a semi-structured interview form. The semi structured form was developed by the researchers.

The first part of the interview form consists of information about the demographic characteristics of the participants; the second part includes the problems experienced by parents in distance education during the Covid-19 pandemic, along with their positive and negative experiences and opinions about this process. These questions are how parents evaluate distance education in the Covid-19 pandemic period, whether the Education Information Network (EIN) is used effectively or not, what kind of problems they experience in this process, whether their children are interested in classes, how often their children participate in classes, how the academic achievement of their children are and what their positive and negative experiences are. Additionally, they are asked about their contributions to the distance education process.

As stated by Saumure \& Given (2008), when non-verbal communication tools on the internet are used, the analysis and interpretation of the data obtained from them is difficult. Semi-structured interviews were conducted to determine what middle school parents think about the effects of the Covid-19 pandemic on middle school education. Within this scope, a Covid-19 Middle School Parent Interview Form (Cov19MSPIF) were developed. The Cov19MSPIF consisted of seven items. All items are open-ended questions which are easy to understand. Two expert middle school teachers and two field educators were consulted. The form was revised based on their feedback. A pilot study was piloted with three middle school parents, and the form was then completed based on their comment on clarity, expressing, significance, and understanding (see Appendix A: "Middle School Parents Interview Form (Cov19MSPIF)").

However, there are some disadvantages of using internet or computer technologies. In this study, some parents refused to participate due to the lack of adequate computer skills. Diverse socioeconomic status, gender, and other factors may have deterred individuals from using internet and digital technologies that were necessary to conduct a virtual research. Due to the Covid-19 pandemic process, face-to-face meetings could not be held with all parents. Thus, the data of Cov19MSPIF has been obtained through "Google Forms".

\subsection{Data Analysis}

In the research, the data were gained through Cov19MSPIF-semi-structured interview questions. Descriptive analysis and content analysis methods were preferred to analyse the data. In the descriptive analysis method, the data obtained by various research methods are arranged, interpreted, and evaluated by providing clear descriptions in accordance with the logic. In addition, while reflecting the opinions of the interviewees, mostly direct quotations were used to draw attention (Görgülü Arı \& Hayır Kanat, 2020). Therefore, the standards and ethics of the Virtual Qualitative Research are considered in the study. 
First, all answers for the Cov19MSPIF were collected online and transcribed. Second, codes were developed. While the data obtained via content analysis are explained through different concepts and relationships, concepts, themes and codes can be determined in advance or created and explained during the analysis (Cohen, Manion \& Morrison, 2007, Sakarya \& Zahal, 2020). Participants were assigned pseudonyms (V1, V2, ... etc.) to ensure confidentiality and to protect their anonymity. Then the coders followed a general coding structure to start but kept an encoding log to convey the necessary changes in structure throughout the coding process. Next, the researchers conducted a thematic analysis using a semideductive approach based on the coding scheme and met weekly to discuss coding decisions and ensure inter-rater reliability (Braun \& Clarke, 2012). Thus, researchers decided the differences by consensus (Campbell, Quincy, Osserman \& Pedersen, 2013).

\subsection{Validity and Reliability}

In order to taken into account, the validity and reliability of the study, content validity was implemented by obtaining the opinions of three field education experts. Each participant was called and asked whether the information in the interview form belonged to them and whether there was anything they would like to add, and thus reliability was ensured. In addition, a code was given to each participant and the data were analysed through the codes. Moreover, the inter-rater reliability calculation formula of Miles \& Huberman (1994, p.100) "Consensus / (Consensus + Disagreement) x 100" was utilized to determine the reliability. As a result of the calculation, the reliability was found to be $88 \%$. Third, categories and themes were determined based on a literature review. The codes were assigned to those categories and themes. Afterwards, the data were analysed using inductive analysis. Fourth, the themes, categories, and codes were tabulated and interpreted. Data were analysed using inductive content analysis. Participants were interviewed, and then, the interviews were transcribed. A total of three independent researchers encoded the transcripts and notes. They developed themes, categories, and codes. They identified the parts on which they agreed and disagreed and discussed those parts to reach a consensus.

\subsection{Research Procedures}

Themes, categories, and codes were presented in tables. Direct quotations were used to provide an accurate and coherent picture of participants' views and to allow readers to easily analyse and interpret the findings (Miles \& Huberman, 1994). The answers given by the parents to the Cov19MSPIF were transformed into themes through content analysis and interpreted accordingly.

Themes in question were organized according to research questions. Then they were divided into four categories by the researchers, which means that parents' comments about research problems were coded into four main conceptual themes: personal barrier, technological barriers, distance-related barriers, educational barriers (Figure 2.) 


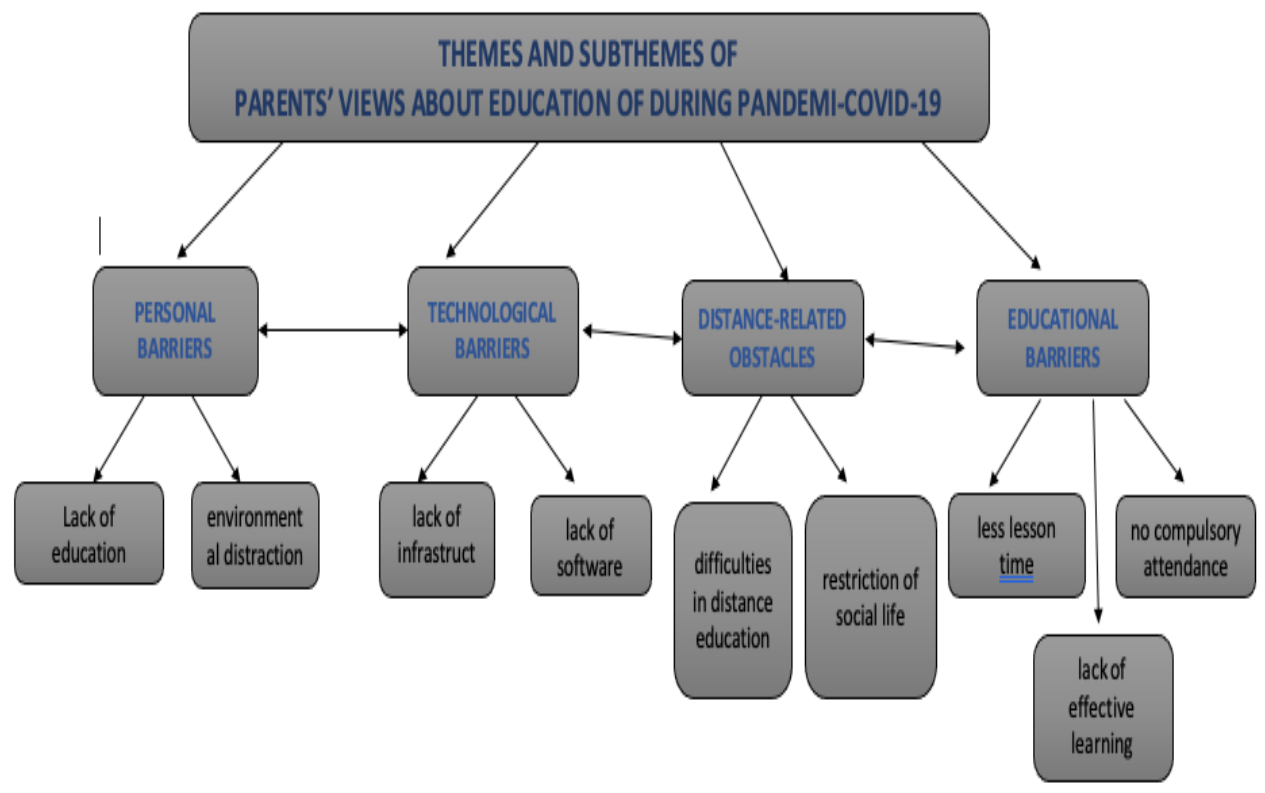

Fig. 2. Themes and subthemes identified regarding parental views on research problems that were coded into four main conceptual themes and sub themes.

- The first theme is personal barriers, and its sub-themes are lack of education and distraction caused by the environment.

- The second theme is technological barriers and its sub-themes are lack of infrastructure and software.

- The third theme is distance-based barriers and its sub-themes are difficulties in distance education and restriction of social life.

- The fourth and the last theme is the barriers stemming from the educational system and its subthemes are less class time, non-compulsory attendance and lack of effective learning.

In this study, we collected the data through the Cov19MSPIF from 20 parents (Figure 1). One person was excluded as she could not be contacted. Two people were excluded because they gave inadequate answers to the questions such as "No, Yes, Positive or Negative". Another person was excluded as she did not give any clear answers to the questions asked, and one person was excluded because she could not be followed in the process.

\subsection{Findings and Discussions}

In this section, research findings should be explained by benefiting from related literature.

Accordingly, the answers to the eight research questions directed to the parents participating in the research are explained in the tables below. The reliability of the research findings was supported by directly quoting the responses of the participants to the interview questions.

\section{Parents' Views Regarding Whether Education Information Network (EIN) Is Used Effectively or Not}

The parents who participated in the study were asked how they evaluated the distance education during the Covid-19 pandemic period and what they thought about the effective use of the Education Information Network (EIN). The frequency distribution of the answers given by the parents to this question is given in Table 2. 


\section{Table 2.}

Frequency distribution regarding whether EIN is used effectively or not

\begin{tabular}{lc}
\hline How do you evaluate the distance education carried out in the Covid-19 pandemic & f \\
period? Do you think Education Information Network (EIN) is used effectively? & 1 \\
\hline Used effectively & 3 \\
Not much effect & 11 \\
\hline Not effective at all & \\
\hline
\end{tabular}

When Table 2 is examined, 11 of the 15 participants did not find Education Information Network (EIN) effective at all, 3 of them thought that it did not have much effect, so it was used occasionally and one thought that it was used effectively.

- The answers given by the parents participating in the research to the first question are presented below by quoting directly.

- The distance education process entered our lives in a very short time. Therefore, we experienced many problems caused by the application. We cannot use the EIN effectively. The electricity is sometimes cut off, so is the internet connection. (V.1)

- Face-to-face classes were more beneficial than online classes. Classes are underestimated in distance education. The EIN is not used effectively. (V.4)

- The EIN is not used effectively. While using the EIN, students only use it for homework and the activities in the lessons are incomplete because they do not study properly. Full learning cannot be achieved. (V.7)

Parents' Opinions on the Problems Experienced in the Distance Education Process during the Covid-19 Pandemic Period

As a second question, the parents who participated in the study were asked what kind of problems they experienced during the Covid-19 pandemic period in the distance education process. The frequency distribution of the answers given by the parents to this question is given in Table 3.

Table 3.

Frequency distribution regarding problems experienced during the covid-19 pandemic distance education process

\begin{tabular}{lc}
\hline $\begin{array}{l}\text { What are the problems you experience during the Covid-19 pandemic distance } \\
\text { education process? }\end{array}$ & f \\
\hline Connection problem of EIN live lesson app & 3 \\
Focus problem on live lessons & 5 \\
Internet and power failure & 2 \\
Inability to see the screen clearly in the live lesson & 1 \\
Connection problem and lack of communication & 2 \\
Short duration of live lessons & 1 \\
Participation in live classes is not compulsory & 4 \\
Distraction due to noise & 4 \\
\hline
\end{tabular}

When Table 3 is examined, it is seen that the most common problem during online classes is the internet connection. This is followed by internet and power outages, along with distraction due to noise. Other problems are as follows: the difficulty in focusing on the lessons, the inability to see the EIN screen clearly, the duration of lesson being short, the participation not being compulsory, and the lack of interaction between the teacher and the student.

The answers given by the participants to the second question regarding the problems encountered are presented below by quoting directly. 
- There were six lesson hours a day, but my child never attended to all six lessons, either because of the system fails or disconnection. Even if the class started, the duration of lessons was very short. The first 5 or 10 minutes were wasted waiting for participants. Since the time was short, children could not have the opportunity to ask questions, so they did not learn effectively. (V.8)

- The problem we experienced the most was not being able to pay attention to the lesson due to environmental noises. My child could not focus because of noises coming from outside. (V.11)

- I found it difficult to get my child to attend to the classes since it was not compulsory to attend the classes. He was reluctantly listening to the lessons. When the electricity was cut, the internet connection was lost, and therefore he was not able to follow the classes properly. (V.9)

Parents' Views Regarding the Interest of Children in the Course of the Covid-19 Pandemic Period Distance Education Process

The third research question was "How did the distance education process affect your children's interest in the lesson during the Covid-19 pandemic period? How can your child's interest in classes be increased?" The frequency distribution of the answers given by the parents is given in Table 4 .

Table 4:

Covid-19 pandemic period of distance education process regarding children's interest in lessons

\begin{tabular}{ll}
$\begin{array}{l}\text { How did the distance education process affect your children's interest in the } \\
\text { lesson during the Covid-19 pandemic? How to help your child get motivated? }\end{array}$ & $\mathrm{f}$ \\
\hline Low interest in attention deficit & 6 \\
His interest decreased due to anxiety about the grade & 2 \\
Interest decreased due to lack of communication & 3 \\
Student's interest decreased due to focusing problem & 4 \\
Student's interest decreased because he could not teach himself & 4 \\
Student's interest decreased due to surrounding sounds and noise & 5 \\
\hline
\end{tabular}

When Table 4 is examined, it was seen that the distance education process affected students negatively. These negative effects included the following: the lack of attention, inability to fully understand the subject, anxiety about grades, difficulty in focusing on the lesson, lack of communication, and environmental noises.

The responses of the participants to the fourth question are presented below by quoting directly.

- When there is a new course book, lesson or computer, classes may be more interesting. However, it was not similar to face-to-face education, even a slight noise was enough to distract my child. So, his attention was quickly lost. (V.15)

- He could not concentrate on the lesson. Since the lesson times were limited, he could not take notes. Active participation could have been achieved as students were not given enough time to take notes and ask questions. I think his interest could have been increased by giving more time. (V.11)

Parents' Opinions Regarding Positive and Negative Experiences in the Distance Education Process During the Covid-19 Pandemic Period

The fourth question was "What are the positive and negative experiences you have in distance education during the Covid-19 period?" The frequency distribution of the answers given by the parents is given in Table 5. 


\section{Table 5.}

Frequency distribution regarding positive and negative experiences during covid-19 pandemic distance education process

\begin{tabular}{llc}
\hline $\begin{array}{l}\text { What are the positive and negative experiences you had in the distance education process during } \\
\text { the Covid-19 pandemic period? }\end{array}$ & f \\
\hline Positive & Home layout was provided (V.2, V.10) & 2 \\
& There has been awareness in the use of technology (V.3) & 1 \\
& There were no problems with service, food and clothing (V.5) & 1 \\
Negative $\quad$ Home layout was not provided (V.1, V.4, V.7, V.9, V.11) & 5 \\
& We have difficulties because we cannot attend live lessons (V.1, V.6, V.8) & 3 \\
& He remained away from the friendship environment and social life was restricted (V.9, & 4 \\
V.12, V.13, V.14) & 3 \\
& Distraction increased due to environmental sounds (V.3, V.11, V.15) & 1 \\
& We are experiencing a decrease in disciplinary control (V.7)
\end{tabular}

When Table 5 examined, it is seen that parents had more negative experiences in the distance education process. Negative experiences are as follows: changes in the home arrangement, experiencing distress because of the lack of attendance, being away from friends, restriction of the social life, distraction by the environmental noises and decrease in discipline. On the other hand, positive experiences involve the following: the change in the layout of the house, the awareness that computers will be used not only for games but also for education, and lowering the expenses such as services, food and clothing.

The answers given by the parents participating in the research to the fourth question are presented below by quoting directly.

- We found it difficult to keep our lives normal at home because we were constantly in online classes. Being away from friends, my child's social life was restricted, and he was bored. (V.9)

- The noises coming from the environment affected the lessons. When the door or the phone rang, my child was distracted and felt uneasy because he could not hear the teacher. He could not take notes on the notebook because of the limited time, and he cried after a period because there was so much writing, which affected us negatively. (V.3)

- We had to teach many things to our child because he did not understand lessons. He got stressed because he could not comprehend. Therefore, it was difficult to keep discipline because of low motivation. (V.4)

Parents' Opinions regarding the Efficiency of the Distance Education Process in the Covid-19 Pandemic Period

The fifth question addressed to parents was: "Do you think the distance education process during the Covid19 pandemic is efficient for your child? Why?" The frequency distribution of the answers given by the parents is given in Table 6 .

Table 6.

Frequency distribution regarding the efficiency of the distance education process in the covid-19 pandemic period

\begin{tabular}{l}
$\begin{array}{l}\text { Do you think the distance education process during the Covid-19 pandemic period is } \\
\text { efficient for your child? Why is that? }\end{array}$ \\
\hline $\begin{array}{l}\text { It is not efficient, it has a focus problem (V.3, V.8, V.11, V.13) } \\
\text { It is not efficient, the subjects are not enough (V.2, V.6, V.7, V.10, V.14) }\end{array}$ \\
$\begin{array}{l}\text { It is not efficient, it is flexible working because there is no separation of school and home (V.12) } \\
\text { It is not efficient, the subjects are not understood due to the distraction (V.1, V.5, V.7, V.9, V.15) }\end{array}$ \\
$\begin{array}{l}\text { It is not efficient because the distance education process is not suitable for all subjects and all age } \\
\text { groups (V.2, V.4) }\end{array}$ \\
\hline
\end{tabular}


When Table 6 is examined, not all parents found the distance education process efficient and stated different reasons. Parents stated that the reason why the distance education process was not efficient was that the subjects were not covered enough. Other reasons can be summarized as follows: having focusing problems, distraction, the inability to separate school and home, and the process not being suitable for all subjects and all ages.

The answers given by the parents to the fifth question are presented below by quoting directly.

- I did not find the distance education process efficient. The distance education process was not suitable for every subject and age level. My son could not understand especially math lessons. Since the lessons were half an hour, there was no time to ask questions. (V.4)

- Distance education process was not efficient. My daughter was bored being at home all day, so she could not fully focus on the lesson. She had difficulties in understanding the issues because she was distracted. (V.15)

Parents' Opinions on the Level of Children's Participation in the Distance Education Process during the Covid-19 Pandemic Period

The sixth question asked the parents who participated in the study was "What are the attendance levels of your children in the distance education process during the Covid-19 pandemic period?" The frequency distribution of the answers given by the parents is given in Table 7 .

\section{Table 7.}

Frequency distribution regarding the levels of child participation in the distance education process during the covid-19 pandemic period

\begin{tabular}{ll}
\hline $\begin{array}{l}\text { What are the attendance levels of your children in the distance education } \\
\text { process during the Covid-19 pandemic period? }\end{array}$ & f \\
\hline Attended most lessons & 5 \\
Mostly unable to attend the first lessons & 3 \\
Could not attend classes due to connection and intermittent problems. & 7 \\
\hline
\end{tabular}

When Table 7 is examined, it is seen that students mostly could not attend the classes because they had internet connection problems, which was followed by the inability to attend the first classes due to sleeping and lack of participation in classes.

The answers given by the parents to the sixth question regarding the levels of their children's participation in the lesson are presented below by quoting directly.

- My daughter could not attend because she could not wake up for the first class. She was indifferent as attendance to classes was not compulsory. Even if she attended to the classes, she did it reluctantly, which was not effective. (V.9)

- When he attended the lesson, he could not follow the lesson effectively because he often disconnected from internet. (V.8)

Parents' Opinions on the Success of Children in the Distance Education Process during the Covid-19 Pandemic Period

The seventh question asked to the parents was "What do you think about the success of your children in the distance education process during the Covid-19 pandemic period?" The frequency distribution of the answers given by the parents is given in Table 8 . 


\section{Table 8.}

Frequency distribution regarding the levels of child participation in the distance education process during the Covid-19 pandemic period

\begin{tabular}{lc} 
What are the attendance levels of your children in the distance education process during the & f \\
Covid-19 pandemic period? & 5 \\
\hline Attended most lessons & 3 \\
Mostly unable to attend the first lessons & 7 \\
Could not attend classes due to connection and intermittent problems. & \\
\hline
\end{tabular}

When Table 8 is examined, it should be noted that 6 parents were unwilling and uninterested about the failure of their children in the distance education process. In addition, it is seen that online courses were not as effective as face-to-face education and there was a decline in success rate.

The answers given by the participants to the seventh question are given below by directly quoting.

- They should not have been promoted to the upper-class last year. Because they did do not know anything related to the second semester, they learnt by heart, the success rate was very low. I think that they did not learn anything properly (V.12)

- The learning process was difficult. Since he could not understand the subject, I tried to support him. As he was unwilling and concerned, his success rate decreased. (V.14)

\section{Parent'Views regarding the Contribution to Children in the Distance Education Process}

The eighth question was: "As a parent, have you contributed to your child in the distance education process? How?" The frequency distribution of the answers given by the parents is given in Table 9.

\section{Table 9.}

Parents' opinions on contributing to children in the distance education process

\begin{tabular}{lc}
\hline $\begin{array}{l}\text { As a parent, have you contributed to your child in the distance education process? What are } \\
\text { they? }\end{array}$ & f \\
\hline I provided a suitable environment for studying. I bought the necessary materials for the course. & 5 \\
(V.1, V.2, V.6, V.8, V.11) & 3 \\
I helped to repeat and reinforce the subject in his lessons and supported their participation in the & \\
lesson. (V.7, V.9, V.14) & 4 \\
I explained the subjects in the lessons by doing research on the subjects he did not understand, and \\
I tried to keep his morale high so that he could enjoy his time outside the lesson. (V.1, V.3, V.6, \\
V.8) \\
I tried to make up for the deficiencies by sending them to the courses in the lessons that I could not \\
help with (V.5, V.15) & 2 \\
I encouraged my child to tend to lessons. (V.9, V.10, V.12) & 3 \\
Since my child's attention was distracted quickly, I was present and supported during the lesson & 1 \\
time. (V.4) & \\
I did not contribute because I could not provide discipline. (V.13, V.1) & 2 \\
I helped with computer related technical glitches. (V.3) & 1 \\
\hline
\end{tabular}

When Table 9 is examined, it is seen that parents contributed to the distance education process by preparing the most suitable environment for their children. In addition, parents supported their children to participate in the lessons and helped them in subjects that they did not understand. Moreover, parents helped their children revise the topics and encouraged them to register for private courses to learn effectively.

Furthermore, parents helped with connection and technical problems, especially when there was a problem with the computer. However, two parents could not contribute because their children had discipline problems. 
The answers given by the parents to the last question are given below, with direct quotations from interviews.

- I was with my child during lessons, his attention was immediately distracted, it was necessary to check whether he understood. I tried to have a good time with my child outside of class to keep her motivation high. (V.7)

- I provided a suitable environment for studying. I helped with technical problems related to the computer, I tried to solve issues. (V.6)

Following this, the themes are organized according to the research questions and summarized in Table 10.

Table 10.

Summary of themes related to parents' views on distance education during the covid-19 pandemic process

\begin{tabular}{|c|c|c|}
\hline Themes & $\begin{array}{c}\text { Sub } \\
\text { Themes/Category }\end{array}$ & Selected Quotations \\
\hline \multirow[t]{2}{*}{ Personal barriers } & Lack of education & $\begin{array}{l}\text { I try to support because most of them do not understand the subject. } \\
\text { Because he was unwilling and concerned, his success also decreased. (V.14) }\end{array}$ \\
\hline & $\begin{array}{l}\text { Environmental } \\
\text { distraction factors }\end{array}$ & $\begin{array}{l}\text { When the door or the phone rings, my child is distracted, bored and uneasy } \\
\text { because he does not understand. (V.3) } \\
\text { The most common problem we experience is not being able to pay attention } \\
\text { to the lesson due to the noise from the environment. My child cannot focus } \\
\text { because of the sounds coming from outside. (V.11) }\end{array}$ \\
\hline \multirow[t]{2}{*}{$\begin{array}{l}\text { Technological } \\
\text { barriers }\end{array}$} & $\begin{array}{l}\text { Lack of } \\
\text { infrastructure }\end{array}$ & $\begin{array}{l}\text { The electricity can be cut off, so the internet connection is cut (V.1) } \\
\text { There are six lesson hours a day, but never attend all six of the lessons, } \\
\text { either the system fails or it kicks it directly from the system. (V.8) }\end{array}$ \\
\hline & Lack of software & $\begin{array}{l}\text { When using Education Information Network (EIN), we only use it for } \\
\text { homework, it is incomplete because the activities in the lessons are not } \\
\text { working properly. (V.7) } \\
\text { When he attends the class, he has to leave the lesson because of the } \\
\text { connection problem, often because he was kicked from the system. (V.8) }\end{array}$ \\
\hline \multirow[t]{2}{*}{$\begin{array}{l}\text { Distance-related } \\
\text { barriers }\end{array}$} & $\begin{array}{l}\text { Difficulties in } \\
\text { distance education }\end{array}$ & $\begin{array}{l}\text { It does not resemble a face-to-face classroom training, even the slightest } \\
\text { noise is enough to distract. That's why his interest quickly dissipates. (V.15) } \\
\text { We have to teach most things because he doesn't understand in the lessons. } \\
\text { He gets stressed because he doesn't understand. In these conditions, it is } \\
\text { difficult to provide discipline because of low motivation. (V.4) } \\
\text { We find it difficult to maintain normal placement in the house because we } \\
\text { are always in class. (V.9) }\end{array}$ \\
\hline & $\begin{array}{l}\text { Restriction of social } \\
\text { life }\end{array}$ & $\begin{array}{l}\text { My daughter is bored because she's always at home, so she can't fully focus } \\
\text { on the lesson. She has difficulties in understanding the subjects because she } \\
\text { is distracted. (V.15) } \\
\text { My child was bored because he was away from his friends and his social } \\
\text { life was restricted. (V.9) }\end{array}$ \\
\hline \multirow[t]{4}{*}{$\begin{array}{l}\text { Obstacles sourced } \\
\text { from the education } \\
\text { system }\end{array}$} & Less lesson time & $\begin{array}{l}\text { No notes are taken due to limited time in lessons. (V.11) } \\
\text { Even if the lesson is attended, the lesson time is very short. The first } 5 \text { minutes } \\
\text { or } 10 \text { minutes of the half hour lesson is spent waiting for a friend. Since the } \\
\text { time is shortened, children don't have the opportunity to ask questions, so } \\
\text { they can't complete their deficiencies. (V.8) } \\
\text { He can't write in the notebook because of the time limit, he cries after a while } \\
\text { because he is bored with so much to write. (V.3) }\end{array}$ \\
\hline & $\begin{array}{l}\text { Lesson attendance is } \\
\text { not compulsory }\end{array}$ & $\begin{array}{l}\text { I find it difficult to get my child to attend the classes as it is not compulsory } \\
\text { to attend the classes. He listens reluctantly. (V.9) }\end{array}$ \\
\hline & $\begin{array}{l}\text { Lack of effective } \\
\text { learning }\end{array}$ & $\begin{array}{l}\text { The class should not have been passed from last year. Because they do not } \\
\text { know anything from the } 2 \text { nd period, they passed the class uniformly, the } \\
\text { success is not very low, it can be said that little. I think it was not successful } \\
\text { because something was not learned properly. (V.12) }\end{array}$ \\
\hline & & $\begin{array}{l}\text { The distance education process is not suitable for all subjects and age levels. } \\
\text { My son cannot understand processing questions, especially in math lessons. } \\
\text { (V.4) }\end{array}$ \\
\hline
\end{tabular}


The answers regarding the parents' views on distance education during the pandemic were collected under four main themes and each of these themes was further divided into sub-themes (Table 10). The themes of the current study are as follows: personal barriers, technological barriers, distance-based barriers and barriers due to the education system. The following sub-themes are examined: under the main theme of 'Personal Barriers': lack of education and distraction due to the environment; under the main theme of 'Technological Barriers': lack of infrastructure and software; under the main theme of 'Distance-Related Barriers': difficulties in distance education and restriction of social life; under the main theme of 'Barriers due to the Education System': less lesson time, non-compulsory attendance and lack of effective learning accordingly.

Following this, we attempted to find answers to the following questions step by step through the generated themes. "How do you evaluate the distance education during the Covid-19 pandemic? Do you think the Education Information Network (EIN) is used effectively?" Hence, the answers to this question included the themes Personal Barriers, Technological Barriers and Distance-Based Barriers. "What are the problems you experience during the Covid-19 pandemic distance education process?" Hence, the answers to this question included the themes Personal Barriers, Technological Barriers and Barriers due to the Education System. "How did the distance education process affect your children's interest in the lesson during the Covid-19 pandemic period? How can your child's interest in classes be increased?" Consequently, the answer to question included the themes Personal Barriers and Barriers Caused by the Education System. "What are the positive and negative experiences you had in the distance education process during the Covid19 pandemic? Why?" Therefore, the answers to this question included the themes Personal Barriers, Technological Barriers and Distance-Based Barriers. "Do you think the distance education process is efficient for your child during the Covid-19 pandemic?" So, the answers to this question included the themes Personal Barriers and Barriers Caused by the Education System. "What are your children's attendance levels in the distance education process during the Covid-19 pandemic?" Therefore, the answers to this question included the themes Technological Barriers and Barriers Arising from the Education System. "What do you think about the success of your children in the distance education process during the Covid-19 pandemic period?" Hence, the answers to this question included the themes Personal Barriers and Barriers due to the Education System. "Have you contributed to your child in the distance education process as a parent? How?" Therefore, the answers to this last question included the themes Personal Barriers and Technological Barriers.

\section{Conclusion and Suggestions}

In this present study, we attempted to elucidate the problems experienced by parents in distance education during the Covid-19 pandemic, along with their positive and negative experiences and their ideas. In the distribution of the demographic characteristics, it is seen that the majority of the participants were women $(67 \%)$, there were more parents between the ages of $25-35(47 \%)$, the majority of the parents were university graduates (47\%), and the majority had two or more children (54\%).

The research aimed to reveal the opinions of parents on distance education during the pandemic process and included a total of 8 questions.

As for the first question, "How do you evaluate the distance education carried out in the Covid-19 pandemic period? Do you think Education Information Network (EIN) is used effectively?" The majority of the parents stated that the Education Information Network (EIN) was not used effectively. They explained that distance education became a part of their lives in a short time and, they did not know how to use it effectively at first. That is, since internet connection was required to log into the Education Information Network (EIN), they emphasized the need for the electricity, i.e., when the electricity was cut off, the internet connection was lost, and their children fell behind as a result.

In addition, they expressed that distance education was not an alternative to face to face education. Accordingly, they should have more information about distance education, especially in terms of the use 
of Education Information Network (EIN) so that they can help their children. In similar studies, it was seen that the internet connection and technical problems affected the distance education process negatively (Bırışc1, 2013; Bayburtlu, 2020; Bakioğlu and Çevik, 2020; Görgülü Arı and Hayır Kanat, 2020).

As for the second question, "What are the problems you experience in distance education during the Covid19 period?" most of the parents complained about the connection problem. They stated that there was an error caused by the system while connecting to the lessons, the system prevented students to attend lessons, so they were not able to fully attend to all lessons. Additionally, the screen could not be seen clearly, and their children could not follow the lessons. Parents expressed that in the first 10 minutes of the lesson, the class was expected to meet, which was a waste of time. That is, the time was short because the lessons were half an hour, and their children could not learn effectively simply because there was no time to ask questions. Moreover, parents stated that there was distraction due to the noise coming from the environment during the lessons and the children had focusing problems. Furthermore, their children did not want to attend to the lesson because it was not compulsory, so parents had difficulty in keeping discipline to attend to lessons. Finally, parents stressed that there was a communication gap between the teacher and the student. It should be noted that lack of interaction has been concluded in similar studies (Barış \& Çankaya, 2016; Külekçi Akyavuz \& Çakın, 2020; Görgülü Arı \& Hayır Kanat, 2020).

As for the third question, "How did the distance education process affect your children's interest in the lesson during the Covid-19 pandemic period? How can your child's interest in classes be increased?" all of the parents stated that their children's interest in the lesson decreased. There are a number of reasons for this: lack of attention, lack of communication, distraction caused by environmental noises, difficulties in focusing, anxiety about grades and lack of motivation. Parents believe that there is no opportunity to take notes due to the short duration of the lesson and it is necessary to ask questions over the notes in order to increase the interest a little.

As for the fourth question, "What are the positive and negative experiences you have in distance education during the Covid-19 period?", the parents stated that distance education was positive because it enabled a learning space at home, increased the awareness of using technology for education instead of playing games, eliminated the need for a service vehicle and decreased meal costs. On the other hand, parents' negative experiences where they could not do the household chores as they were constantly in class - in every room of the house-, their children were bored because they were not maintaining social relations and their social life was restricted; their children could not understand many issues because they could not attend live lessons, and they had to study themselves. Therefore, poor performance led to depression and restlessness which had a negative effect on the children. The low motivation level in students was in parallel with the study of Sintema (2020).

As for the fifth question, "Do you think the distance education process during the Covid-19 pandemic is efficient for your child? Why? all parents claimed that the distance education process was not efficient for their children. In addition, parents stated that the process was difficult and troublesome for their children. They also believe that distance education did not contribute to the learning. Following this, parents explained that even a slightest noise distracted their children, and therefore they could not understand the subject. In addition, parents shared their concerns about the settings. That is, even if a school environment was created at home, there was no comfortable studying environment because there was no separation between school and home, so the distance education process was not suitable for every subject and every age level, especially for practical and interactive subjects. For example, first grade students had a lot of difficulties in learning how to read and write online. Similarly, Özköse et al. (2013) asserted that the distance education was not suitable for applied and interactive lessons.

As for the sixth question, "What are the attendance levels of your children in the distance education process during the Covid-19 pandemic period?" most of the parents stated that their children could not attend the classes due to the connection problems. According to parents, the reason why children could not attend the first lessons was that they could not wake up in the morning and they were indifferent because there was 
no compulsory attendance. Additionally, parents stated that even if their children attended to the lesson, their children had to be disconnected from the lesson due to technical problems, and therefore their desire to participate in the lesson decreased. Barış \& Çankaya (2016) and Bakioğlu \& Çevik (2020) concluded that the participation rate of students in classes is low in distance education. This result is consistent with the present study.

As for the seventh question, "What do you think about the success of your children in the distance education process during the Covid-19 pandemic?" the parents stated that they had doubts as to whether their children could be successful in this newly adopted process. Parents also added that they could not benefit from the lessons compared to face-to-face education. Additionally, their children did not have the opportunity to ask questions to make up their deficiencies because the lessons were half an hour, which resulted in their children preferring to play games instead of learning.

Following this, several parents whose children took a written exam were interviewed again and asked about their children's success. The parents stated that their children had difficulties in the written exams, that they tried to help their children by studying the subject during the preparation stage for the exam, and that they tried to complete their deficiencies in this way. However, they expressed that their children's success declined as they could not learn subjects as effective as face-to-face education.

As for the eighth question, "As a parent, have you contributed to your child in the distance education process? How?" some parents stated that they prepared suitable environments for their children to study and provided their children with whatever material was required for the lesson. Besides, parents gave their children some help in matters that they did not understand in their lessons, i.e. they revised the subject together and encouraged their children to participate in the lesson as a result. In addition, parents stated that during the pandemic they attempted to keep their children's motivation and morale high. Moreover, parents held positive attitudes towards their children's problems, especially when they had problems with the computer and Internet. Furthermore, when parents could not help in lessons that their children did not understand, they had their children register for private courses. Following this, parents expressed that they were with their children especially during the live lessons so that their children could not be distracted and adapt to the lesson accordingly. Finally, parents were constantly monitoring their children, and attempted to have a pleasant time with their children. The results obtained from the research questions are briefly given in Figure 3. 


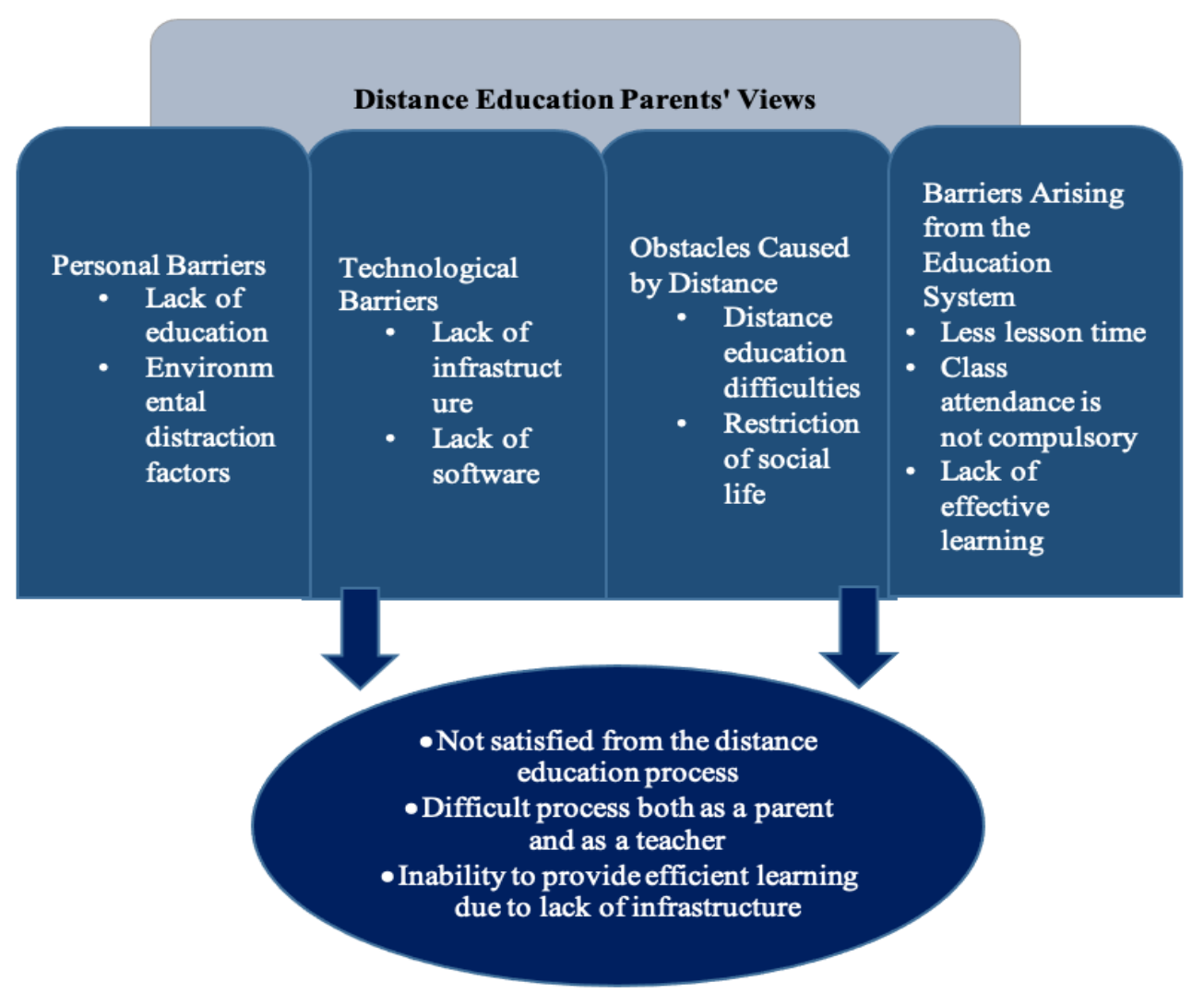

Fig. 3. Results regarding parents' views on distance education during the covid-19 pandemic process

In Figure 3, the results of parents' opinions regarding distance education during the pandemic process are summarized under two subtitles as Personal Results and Technical Problems. It is worth considering that the parents were not satisfied with the distance education process, along with the difficulties in the process, and therefore they did not consider the process as a way of building knowledge due to the lack of infrastructure. As far as the results of the study are concerned, we think that the parents were unhappy with the distance education process by having difficulties both as parents and teachers through this process. They were also worried that they had discipline problems regarding their children. Additionally, there were infrastructure problems related to the Education Information Network (EIN) system, and therefore their children were unsuccessful because of connection problems, which resulted in parents being worried. Considering the results of the research, the reasons are summarized in Figure 4. 


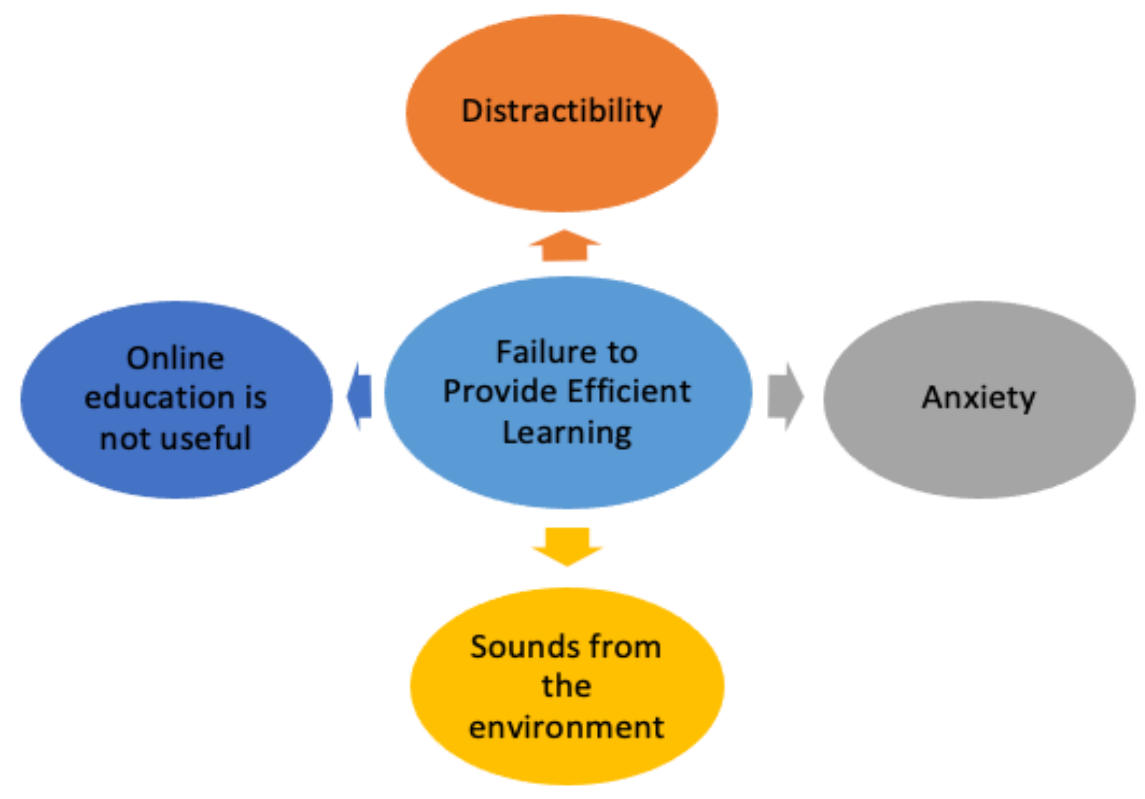

Fig. 4. Reasons for failure to provide efficient learning

In Figure 4, it is seen that online education was not as effective as face-to-face education. Distraction, anxiety, and environmental noises were the main reasons. Accordingly, activities can be organized to increase the students' interest. That is, by developing learning systems that allow students to benefit from digital content such as blended learning, which occurs with the combination of education system and internet technologies, students can be encouraged to have more effective learning experiences. In addition, educational-didactic, relaxing and encouraging activities can be organized to reduce students' anxiety. Furthermore, the distance education system can be strengthened by developing infrastructure and maintenance. Following this, training can be organized to help their children learn more efficiently in the distance education process and contribute to their awareness. Finally, it is quite important to conduct similar studies on a larger scale to identify the problems encountered during the pandemic period education process.

Some participants explained that parental controls were useful to manage the content that their children have access to such as social media applications or TV streaming services. All participants expressed some concern about the time spending in front of screens. A parent wished a more restrictive approach to monitor her children's technology use. Some parents stated that they had difficulty in monitoring their children's activities due to technological incompetence. Also, some parents expressed disappointment about the lack of resources. Similarly, some parents mentioned the lack of resources within the school and Internet systems. Many parents had contacted teachers, school counsellors, or administrators to help their children who had difficulty in studying.

The middle school parents are emphasised that the Covid-19 pandemic has had an adverse impact on teaching concepts, teacher-student interaction, face-to-face education, and learning by doing. On the other hand, some parents consider that the Covid-19 pandemic has been improved parental engagement and student-parent interactions. The period of Middle School education is prepared children for high school. It can be concluded that the Covid-19 pandemic has a negative effect on middle school education. Hornby \& Lafaele (2011) and Nakamura (2000) asserted that parents give some challenges such as the lack of resources, internet, computer, low self-confidence, low concentration to lesson, reduces motivation. Similar results have been reported by earlier studies (Hornby \& Lafaele 2011; Nakamura 2000). Parent-student communication problems had a negative effect on education (Wherry 2009).

As a conclusion, the study focused simply on parent perspectives. Another result of the study is that teachers spent huge amounts of time. The teachers spent time for answering questions, working with students individually or in groups. In addition to this, during the pandemic, teachers needed to communicate with 
concerned parents. This means that the world of teaching and learning has changed dramatically. The teachers, students, and parents have to keen on technology to continue classes and teaching and learning activities. Hence, during the pandemic, our students and their families are away from schools. For this, we connect with them using technology. It seems that the teachers or parents have to face with this reality, which is now referred to as 'a new normal'. For teachers, students and parents, due to Covid-19, all textbooks such as mathematics need curriculum developers and textbook authors to include suitable practical examples in curricula and textbooks.

When education is interrupted, some recommendations can be made to maintain middle school education. Those are providing families with free internet access, starting an EIN-TV channel, preparing distance education programs and guidebooks for parents, teachers, students and organizing in-service trainings. Teachers and parents have come across numerous problems during the Covid-19 pandemic. Authorities should pay attention those problems and to create plans to sustainable distance education. This study suggested that families should be provided with free internet access, guidebooks. The MEB must be given them training in sustainable distance education during outbreaks. The MEB must also give to teacher's technology-based education, TPACK (Technological Pedagogical Content Knowledge) education, so that they could help their students during outbreaks.

This study will come up with a basis for all stakeholders of distance education. Policymakers should be getting strategies for sustainable school education during outbreaks. In this period, epidemics should be included in detailed in the content of education programs. Parents should also be involved in the implementation process of educational programs. We believe the study will pave the way for further research into the impact of the Covid-19 pandemic on students, parents and teachers, and the challenges parents and teachers will face.

\section{Appendix A:}

\section{Parent Interview Form (Cov19MSPIF)}

1. How do you evaluate the distance education carried out in the Covid-19 pandemic period? Do you think Education Information Network (EIN) is used effectively?

2. What are the problems you experience during the Covid-19 pandemic distance education process?

3. How did the distance education process affect your children's interest in the lesson during the Covid-19 pandemic? How to help your child get motivated?

4. What are the positive and negative experiences you had in the distance education process during the Covid-19 pandemic period?

5. Do you think the distance education process during the Covid-19 pandemic period is efficient for your child? Why is that?

6. What are the attendance levels of your children in the distance education process during the Covid19 pandemic period?

7. What do you think about the success of your children in the distance education process during the Covid-19 pandemic period?

8. As a parent, have you contributed to your child in the distance education process? What are they?

\section{References}

Aslanargun, E. (2007). The review of literature on school-parent cooperation and students' school success. Manas Üniversitesi Sosyal Bilimler Dergisi, 9(18), 119-135 Retrieved from https://dergipark. org.tr/tr/pub/manassosyal/issue/49947/640068.

Arslan, F., Korkmaz, Ö. (2019). İlahiyat lisans tamamlama uzaktan eğitim öğrencilerinin etkileşim kaygıları ve uzaktan eğitime dönük tutumları. Ahmet Keleşoğlu Eğitim Fakültesi Dergisi, 1(1), 12 25 . 
Bakker, A., \& Wagner, D. (2020). Pandemic: lessons for today and tomorrow? Educational Studies in Mathematics, 104, 1-4.

Bakioğlu, B., Çevik, M. (2020). Covıd-19 pandemi sürecinde fen bilimleri öğretmenlerinin uzaktan eğitime ilişkin görüşleri. Turkish Studies, 15(4), 109-129.

Barış, M., Çankaya, P. (2016). Akademik personelin uzaktan eğitim hakkındaki görüşleri. International Journal of Human Sciences, 13(1), 399-413.

Bayburtlu, Y. S. (2020). Covid-19 pandemi dönemi uzaktan eğitim sürecinde öğretmen görüşlerine göre türkçe eğitimi. Turkish Studies, 15(4), 131-151.

Birişçi, S. (2013). Video konferans tabanlı uzaktan eğitime ilişkin öğrenci tutumları ve görüşleri. Journal of Instructional Technologies \&TeacherEducation JITTE, 1(2), 24-40

Budak, F., Korkmaz, Ş. (2020). Covıd-19 pandemi sürecine yönelik genel bir değerlendirme: Türkiye örneği. Sosyal Araştırmalar ve Yönetim Dergisi, 1(1), 62-79.

Büyüköztürk, Ş., Kılıç Çakmak, E., Akgün, Ö.E., Karadeniz, Ş. ve Demirel, F. (2017). Bilimsel Araştırma Yöntemleri (23. Baskı). Ankara: Pegem Yayınları.

Eğitim Bilişim Ağı [EBA]. (2020). EBA TV lesson broadcast. Retrieved from http://www.eba.gov.tr/

Castro, M., Exposito-Casas, E., Lopez-Martin, E., Lizasoain, L., Navarro-Asencio, E., \& Gaviria, J. L. (2015). Parental involvement on student academic achievement: a meta-analysis. Educational Research Review, 14, 33-46. https://doi.org/10.1016/j. edurev.2015.01.002

Creswell, J. W. (2007). Qualitative Inquiry And Research Design: Choosing Among Five Approaches (2nd ed.). Thousand Oaks: Sage Publications.

Elçiçek, M. (2021). Tendencies in Turkey-based academic studies on distance education during the covid19 pandemic. Journal of Educational Technology \& Online Learning, 4(3), 406-417.

Ewing, J. (2020). Teachers in the pandemic. https://www.forbes.com/sites/johnewing/2020/04/17/teachersin-the-pandemic/\#71b97 20a8646. Accessed 19 December 2020.

Görgülü, Arı, A., Hayır Kanat, M. (2020). Covid-19 (koronavirüs) üzerine öğretmen adaylarının görüşleri. Van Yüzüncü Yıl Üniversitesi Sosyal Bilimler Enstitüsü Dergisi, Salgın Hastalıklar Özel Sayısl, 459492.

Karpman, M., Gonzalez, D. and Kenney, G. M. (2020). Parents Are Struggling to Provide for Their Families during Pandemic, Urban Institute. https://www.urban.org/sites/default/files/publication/102254/parents-are-struggling-to-providefor-their-families-during-the-pandemic_2.pdf

Külekçi Akyavuz, E., Çakın, M. (2020). Covid-19 salgınının eğitime etkisi konusunda okul yöneticilerinin görüşleri. Turkish Studies, 15(4), 723-737.

Miles, M. B. \& Huberman, A. M. (1994). Qualitative Data Analysis. Thousand Oaks, Sage Publication.

Özköse, H., Arı, S., Çakır, Ö. (2013). Uzaktan eğitim süreci için SWOT analizi. Middle Eastern \& African Journal of Educational Research, 5, 41-55.

Patton M. (2002). Qualitative Evaluation and Research Methods, 1990 (2nd editon) Newbury Park Sage.

Sakarya, G., Zahal, O. (2020). Covid-19 pandemi sürecinde uzaktan keman eğitimine ilişkin öğrenci görüşleri. Turkish Studies, 15(6), 795-817.

Sintema, E. J. (2020). Effect of COVID-19 on the performance of grade 12 students: implications for STEM education. EURASIA Journal of Mathematics, Science and Technology Education, 16(7), 1-6. 
Y1ldırım, A., \& Şimşek, H. (2011). Sosyal Bilimlerde Nitel Araştırma Yöntemleri [Qualitative research Methods In The Social Sciences]. İstanbul: Seçkin Yayınları.

Wadley, J. (2020). This is the impact home-schooling is having on parents. https://www.weforum.org/agenda/2020/09/covid19-home-child-education-depression-anxietyhardware-education-tools. Accessed 23 September 2020. 